\title{
Strengthening the 21st Century Skills of Elementary School Students through the Implementation of Project Based Learning
}

\author{
Riyadi \\ Primary Teacher Education Department \\ Universitas Negeri Surabaya \\ Surabaya, Indonesia \\ Riyadi@mhs.unesa.ac.id
}

\author{
Yuni Sri Rahayu \\ Biology Department \\ Universitas Negeri Surabaya \\ Surabaya, Indonesia \\ yunirahayu@unesa..ac.id
}

\begin{abstract}
The purpose of this study is to improve the 21st century skills on elementary school students through the implementation of project based learning. These skills play an important role for students to survive. This study was conducted on 24 students of Public Elementary School in Indonesia, of which were divided into 6 groups consisting of 4 students. This study was conducted in 2 meetings. The first meeting was done by building the students' same perceptions about the projects applied, preparing the projects and schedules with the students, and doing additional tasks outside of classroom activities. At the second meeting, students did performance related with displaying their project results and are assessed on cooperation level, skills in using tools/media, how to obtain the learning or information sources, and ability to express ideas. The three best performances were chosen to be presented in front of their parents. Results showed that the implementation of project based learning was able to promote positive effects on students' skills based on the assessment components.
\end{abstract}

Keywords- Project Based Learning, the 21st century skills, elementary school students

\section{INTRODUCTION}

The characteristic of the $21^{\text {st }}$ century lies on the integrated or synergic knowledge. In accordance with the use of information and communication technology in education sector, it is proven that there are no more obstacles related with times and spaces, the determinant factors of the acceleration and success of knowledge mastery. The foundation of education is an effort to make humans survive and protect themselves from any forms of threats, yet to organize humanto-human relationships [1]. One demand of the $21^{\text {st }}$ century education is to prepare students to compete in the real word, so that learning process must reflect the real-word examples, applications, and experiences either inside or outside classroom activities [2]. One example of such learning materials or processes can be conducted by creating an application of the concept of leaning materials. This is due to the strong and meaningful knowledge and skills that can be constructed through given authentic assignments and works [3].

Project Based Learning (PBL) that contains problem solving will create an authentic learning process [4]. That is, the implementation of such learning model is important to improve students' critical thinking skills and to promote an independent learning. As a constructive learning model, PBL serves students with real-word problems, so that it can bear a permanent and prominent knowledge [3]. In short, it is a model that can organize various projects in learning [5]. The focus of this model lies on the core concepts and principals of a discipline which involves students in investigating problem solving and other meaningful tasks, giving students' opportunity to work autonomously on constructing their knowledge and producing products [6]. The products made by them during the project implementation are authentically able to be assessed by teachers, lecturers or other educational instructors. Thus, in PBL, teachers are less active and conduct direct training, however, they still become an assistance and a facilitator, yet understanding students' thought [7].

The results of observations conducted in one of public elementary schools in Ngawen, Gunung Kidul, Yogyakarta city, showed that the teachers still implemented teachercentered learning model. The used method is still in the form of lecturing mode, so that students tended to act passively. Moreover, the teachers rarely used learning tools or media, so that the learning became ineffective. Also, students less experienced in group works so that it promoted a selfish value. They were also shy to ask questions and to shout ideas.

To cope with above phenomena, it is important to apply a learning model that can prepare students to have learning skills and innovations, skills to use technology and information, ability to work in groups, and life skills. To develop the $21^{\text {st }}$ century education model, teachers must begin with a good step namely changing the paradigm of learning model, from teacher-centered to student-centered models [8], one of which is by implementing PBL for elementary school students.

\section{METHOD}

This study was categorized in pre-experimental design with one shot case study. The participants of this study were 24 fifth graders of an Indonesian public elementary school, divided into 6 groups with 4 students each group, of which also implement PBL. The learning process were conducted in some stages [9] described as follows. 


\section{A. Starting Essential Questions}

Important questions were addressed to students in every beginning of each meeting as a brainstorming activity. It started with choosing a relevant and authentic topic, then, investigating the topic in depth. Teachers should control the relevance and authenticity in order to be beneficial for the students.

\section{B. Designing a Plan for the Project}

Planning was done collaboratively between teachers and students. Thus, students are expected to have self-belonging to the projects they would conduct. This stage consisted of the rules of the game, the selection of an activity that supports and answers the essential question, by integrating among possible subjects, yet knowing kinds of tools and materials that can be easily accessed to assist project accomplishment.

\section{Creating a Schedule}

Both teachers and students arrange the schedule of activities to finish the projects collaboratively. The activities might cover (1) creating timeline to finish the projects, (2) determining deadline of accomplishment, (3) stimulating students to have another plan, (4) guiding students when they made irrelevant ways to the projects, and (5) asking students to make rationales over choosing a particular way/method.

\section{Monitoring Both Students and Their Project Progresses}

Teachers are responsible for monitoring students' activity during accomplishing the projects. The monitoring process could be done by facilitating students in every process. In other words, teachers acted as mentors for students. To ease the monitoring process, a developed rubric would help to record whole crucial activities.

\section{E. Assessing the Outcomes}

Assessment was done to assist teachers in measuring the standard of achievements, of which is useful to evaluate each student's development, to give feedbacks about the level of students' perceived understanding, and to help teachers organize future learning strategy.

\section{F. Evaluating the Experiences}

In the end of learning process, teachers and students did reflection of all activities, including but not limited to the products of the projects. This phase can be done individually or in groups. In this stage, students were asked to express feelings and experiences during the project accomplishment. Both teachers and students develop a discussion that can improve the learning performance, thus, it was found a new inquiry to answer the addressed problems at the beginning of PBL phases.

The data were collected during two meetings conducted. In the first meeting, students were asked to watch a video about a water recycle and some diseases caused by drinking calcareous water. Then, they discussed about their responses to what they had watched. In this meeting, they were expected to understand the water recycle and to know the importance of health especially in consuming water. The next task was that the students, in groups, were asked to explore the ideas using media and other relevant sources, then, to find data of things that can be used in water purification. The results of the task were to get things that can purify water, afterwards, students needed to compose a simple report.

Then, students were divided into two groups based on their ability in conducting research on soil type and water condition in their nearby environment. It was expected that students can measure the level of water cleanness using provided tools. After getting the data, the data analysis and conclusion were essential to draw as the last step of examination.

Form the conclusion, students were guided to make a solvency of the dirty water problem. The next task was that the students were asked to do exploration through media and available sources to find things that can purify water. The expectation was that the students could find information about things that can be used in water purification.

Further, in the second meeting, teachers give a direction about conducting a group work (designed as a competition-like activity) to provide a simple water purification tool from provided media. The composition of the media, including how it is constructed, was determined by each group as the students can discover the tool by themselves. The winner would be chosen based on how the tool functioned as a purify water. (The level of water cleanness was measured by using purification measuring tool).

The best group was chosen as the one who presented in front of parents and nearby society. The presentation was expected to build society awareness about the importance of health especially as a clean drinking water consumed by the society daily. The activity was ended with the feedbacks given by the nearby society.

Student's evaluation was done covering cooperative level, skills to use tools/media, how to obtain information/learning sources, and ability to express ideas. The data analysis was done descriptively.

\section{RESULTS AND DISCUSSION}

\section{A. Results}

TABLE I. THE SCORES OF EACH PARAMETER SHOWN IN GROUPS

\begin{tabular}{|c|c|c|c|c|c|c|c|}
\hline \multirow{2}{*}{ No } & \multirow{2}{*}{ Parameters } & \multicolumn{6}{|c|}{ Group } \\
\hline & & $I$ & II & III & $I V$ & $V$ & $V I$ \\
\hline 1 & Cooperation level & 4 & 4 & 4 & 3 & 4 & 4 \\
\hline 2 & $\begin{array}{l}\text { Skills in using } \\
\text { tools/media }\end{array}$ & 3 & 4 & 4 & 3 & 4 & 3 \\
\hline 3 & $\begin{array}{l}\text { Obtaining the } \\
\text { information/learning } \\
\text { resources to solve the } \\
\text { problem }\end{array}$ & 3 & 3 & 3 & 3 & 3 & 3 \\
\hline 4 & $\begin{array}{l}\text { Ability to express } \\
\text { ideas }\end{array}$ & 4 & 3 & 4 & 4 & 3 & 4 \\
\hline \multirow{3}{*}{\multicolumn{2}{|c|}{$\begin{array}{l}\text { Total Score } \\
\text { Total Final Calibration }\end{array}$}} & 14 & 14 & 15 & 13 & 14 & 14 \\
\hline & & 87.5 & 87.5 & 93.7 & 81.2 & 87.5 & 87.5 \\
\hline & & 0 & 0 & 5 & 5 & 0 & 0 \\
\hline
\end{tabular}

The criteria to determine the level of success is by getting 75 from the range $0-100$, of which is relevant to the passing 
grade of Science subject. Thus, the scores for four parameters applied, then, are converted into ranges $0-100$ (see Table 2).

TABLE II. THE FINAL SCORES OF EACH GROUP

\begin{tabular}{lllll}
\hline No & Name & $\begin{array}{c}\text { Total } \\
\text { Score }\end{array}$ & $\begin{array}{c}\text { Converted } \\
\text { Final } \\
\text { Calibration }\end{array}$ & Note \\
\hline 1 & Group I & 14 & 87.50 & Successful \\
2 & Group II & 14 & 87.50 & Successful \\
3 & Group III & 15 & 93.75 & Successful \\
4 & Group IV & 13 & 81.25 & Successful \\
5 & Group V & 14 & 87.50 & Successful \\
6 & Group VI & 14 & 87.50 & Successful \\
Average & & 87.50 & \\
\hline
\end{tabular}

According to Table 3.2, the data showed that all groups passed the minimum passing grade (75). To clear the portrayals, the lowest score was gotten by Group IV with 81.25, while the highest one was gotten by Group III with 93.75. Thus, Group III became the representative to exhibit the result of the project in front of parents and surrounding society living near to the school. The average score gotten by the class showed excellence in learning process.

\section{B. Discussion}

Based on above analysis results, there is a positive influence between PBL with elementary school students' achievement in term of four indicators that can support the skills needed in the $21^{\text {st }}$ century namely cooperative level, skills in using tools/media to solve the problem, obtaining the information/learning resources, and ability to express ideas (see Table 1 and 2). This is supported by a study conducted by Lasauskiene and Rauduvaite [10] that states that the implementation of PBL can improve a skill to create creative atmosphere which can support sustainable professionalism. Even, in coping with higher education level, this type of model can build lecturer's professionalism competence to create learning method that can stimulate student's activity, build cooperation, and support students to create sustainable knowledge. Chiang, C. L. and Lee, H. [11] also argued that PBL can give positive effect on student's ability, especially in term of building motivation and student's awareness.

In addition, the implementation of PBL is the application of concepts that is already proper theoretically as a basis of solving real-word problems. This is relevant with the $21^{\text {st }}$ century demands that ask students to possess soft skills retracted from the learned concepts. Hutasuhut (2010) stated that projects associated with PBL focus on questions or problems that can lead students to experience real-word concepts or principles [12]. Moreover, Hixson, et al (2012) showed that the implementation of PBL can improve students' $21^{\text {st }}$ century skills [13].

PBL is expected to improve the $21^{\text {st }}$ century skills so that students become more intelligent, dynamic, and full of recent information. Students need to filter and benefit all information spread in any form of media, especially to solve their daily problems. Besides, they have a good connection with international society so that factors of collaboration, communication and teamwork are considered important to determine students' success. Moreover, they also face a global challenge. Thus, since the traditional learning process does not meet students' needs and cannot develop the skills to face the $21^{\text {st }}$ century challenges, it is necessary to build an active classroom by involving students' participation in making a product through an innovative learning model, such as PBL [14].

\section{CONCLUSION}

The results showed that the implementation of Project Based Learning (PBL) is able to reveal a positive effect on students' skills regarding the four assessment components namely cooperation level, skills in using tools/media, obtaining the information/learning resources, and ability to express ideas.

\section{REFERENCE}

[1] S. Freud, Das Unbehagen in der Kultur. Frankfurt: Fischer Taschenbuch Verlag, 2007

[2] I. et al. Yusuf, "Pengembangan Perangkat Pembelajaran Fisika Modern Berbasis Media Laboratorium Virtual Berdasarkan Paradigma Pembelajaran Abad 21 dan Kurikulum 2013," Pancaran, vol. 4, no. 2, pp. 189-200, 2015.

[3] M. Rais, "Model Project Based-Learning sebagai Upaya Meningkatkan Prestasi Akademik Mahasiswa," J. Pendidik. dan Pengajaran, vol. 43, no. 3, pp. 246-252, 2010.

[4] J. T. Hope and W. Allen, "Student Competitive Events: A Strategy for Integrating a STEM Block in Public Schools," Clear. House A J. Educ. Strateg. Issues Ideas, vol. 83, 2010.

[5] D. H. Iwamoto, J. Hargis, and K. Vuong, "The Effect of Project-Based Learning on Student Performance: An Action Research Study," Int. J. Scholarsh. Technol. Enhanc. Learn., vol. 1, no. 1, pp. 24-42, 2016.

[6] F. Movahedzadeh, R. Patwell, J. E. Rieker, and T. Gonzalez, "ProjectBased Learning to Promote Effective Learning in Biotechnology Courses," Educ. Res. Int., vol. 2012, pp. 1-8, 2012.

[7] I. Ilter, "A study on the efficacy of project-based learning approach on Social Studies Education: Conceptual achievement and academic motivation," Educ. Res. Rev., vol. 9, no. 15, pp. 487-497, 2014.

[8] I. Miftari, "Project based learning: Developing 21st Century collaborative and technology skills," Eur. J. Res. Educ., 2013.

[9] "Instructional Module Project Based Learning," The George Lucas Educational Foundation, 2005. [Online]. Available: $\mathrm{http}: / /$ www.edutopia.org/modules/PBL/whatpbl.php.

[10] J. Lasauskiene and A. Rauduvaite, "Project-Based Learning at University: Teaching Experiences at Lecturers," Procedia-Soc. Behav. Sci., no. 197, pp. 788-792.

[11] C. L. Chiang and H. Lee, "The Effect of Project-Based Learning on Learning Motivation and Problem-Solving Ability of Vocational High School Students," Int. J. Inf. Educ. Technol., vol. 6, no. 9, pp. 709-712, 2016.

[12] S. Hutasuhut, "Implementasi Pembelajaran Berbasis Proyek (ProjectBased Learning ) Untuk Meningkatkan Motivasi dan Hasil Belajar Mata Kuliah Pengantar Ekonomi Pembangunan pada Jurusan Manajemen Fe Unimed," Pekbis J., vol. 2, no. 1, 2010.

[13] N. K. Hixson, J. Ravitz, and A. Whisman, Extended professional development in project-based learning: Impacts on 21st century teaching and student achievement. Charleston, WV: West Virginia Department of Education, Division of Teaching and Learn-ing, Office of Research, 2012.

[14] S. P. Devkota, D. R. Giri, and S. Bagale, "Developing 21st Century Skillls Through Project-Based Learning in Efl Context: Challenges and Opportunities," Online J. New Horizons Educ., vol. 7, no. 1, pp. 47-52, 2017. 